Original Research Paper

\title{
Kebun Kopi Arabika Sembalun Bumbung Sebagai Alternatif Destinasi Agrowisata
}

\author{
M. Sarjan ${ }^{1}$, Lalu Ishadi Darwinata ${ }^{2}$, Septia Antasari ${ }^{3}$, Bambang Setiadi Azhari ${ }^{4}$, Achmad Wiranadi \\ Hakim $^{5}$, Muh. Thoriq Dwi Setyawan'

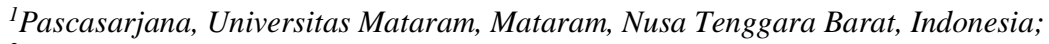 \\ ${ }^{2}$ Teknik Elektro, Fakultas Teknik, Universitas Mataram, Mataram, Nusa Tenggara Barat, Indonesia; \\ ${ }^{3}$ Ilmu Hukum, Fakultas Hukum, Universitas Mataram, Mataram, Nusa Tenggara Barat, Indonesia; \\ ${ }^{4}$ Teknik Mesin, Fakultas Teknik, Universitas Mataram, Mataram, Nusa Tenggara Barat, Indonesia; \\ ${ }^{5}$ Teknik Sipil, Fakultas Teknik, Universitas Mataram, Mataram, Nusa Tenggara Barat, Indonesia; \\ ${ }^{6}$ Teknik Elektro, Fakultas Teknik, Universitas Mataram, Mataram, Nusa Tenggara Barat, Indonesia;
}

https://doi.org/10.29303/jpmpi.v3i2.872

Sitasi: Sarjan, M., Darwinta, L. I., Antasari. S., Azhari, B. S., Hakim, A. W., \& Setyawan, M. T. D. (2021). Kebun

Kopi Arabika Sembalun Bumbung Sebagai Alternatif Destinasi Agrowisata. Jurnal Pengabdian Magister Pendidikan $I P A, 4(3)$

\section{Article history}

Received: 15 Juli 2021

Revised: 31 Juli 2020

Accepted: 18 Agustus 2021

*Corresponding Author: M.

Sarjan, Pascasarjana,

Universitas Mataram, Mataram,

Nusa Tenggara Barat,

Indonesia;

Email: msarjan@unram.ac.id
Abstract: Penulisan ini menggunakan metode deskriptif dan evaluatif. Tujuan penulisan ini untuk memperluas pengetahuan, pengalaman rekreasi, dan hubungan usaha dibidang pertanian. Sektor pariwisata merupakan salah satu sektor yang saat ini sedang digalakkan oleh pemerintah. Hal ini disebabkan karena pariwisata mempunyai peran yang sangat penting dalam pembangunan Indonesia khususnya sebagai devisa negara. Pembangunan pariwisata menjadi salah satu sektor yang diunggulkan saat ini. Pembangunan kepariwisataan memerlukan perencanaan dan perancangan yang baik. Sektor pariwisata memberikan kesempatan tumbuhnya berbagai usaha ekonomi yang dilakukan oleh masyarakat dan membuka lapangan kerja baik formal maupun informal bagi masyarakat. Wisatawan memperoleh pengalaman dari budaya lokal, sementara penduduk lokal memainkan jenis edukasi tentang lingkungan spesifik lokal dan mendapatkan penghasilan. Partisipasi masyarakat memiliki peran penting dalam pengembangan pariwisata agro. Agrowisata merupakan bagian dari objek wisata yang memanfaatkan usaha pertanian sebagai objek wisata. Tetapi juga wisata ini menjadi sarana pendidikan serta hiburan yang menarik bagi para wisatawan. Agrowisata yang berdaya saing dan secara ekonomi dapat dirasakan manfaatnya oleh masyarakat terkait dengan produk yang dihasilkan dan dikonsumsi oleh wisatawan. Namun hal ini juga dialami oleh masyarakat sembalun. Dimana Kebun kopi sembalun mempunyai potensi agrowisata yang cukup baik, namun terdapat pula kelemahan seperti keterbatasan dana, kurangnya sarana dan prasarana penunjang, serta kurangnya atraksi wisata yang ditawarkan. objek wisata yang ditawarkan bersifat rekreasi dan edukatif.

Keywords: Pariwisata; Kopi; Agro Wisata.

dikembangkan sebagai daya tarik potensial untuk pengembangan pariwisata. Sektor pariwisata merupakan salah satu sektor yang saat ini sedang digalakkan oleh pemerintah. Hal ini disebabkan

\section{Pendahuluan}

Indonesia merupakan suatu negara agraris yang

memiliki potensi alam yang dapat


karena pariwisata mempunyai peran yang sangat penting dalam pembangunan Indonesia khususnya sebagai devisa negara.

Pembangunan pariwisata menjadi salah satu sektor yang diunggulkan saat ini. Proses pengembangan pariwisata itu dapat terjadi secara cepat atau lambat, tergantung dari berbagai faktor eksternal (dinamika pasar, situasi politik, ekonomi makro) dan faktor eksternal di tempat yang bersangkutan, kreativitas dalam mengelola aset yang dimiliki, dukungan pemerintah dan masyarakat. Pembangunan kepariwisataan memerlukan perencanaan dan perancangan yang baik. Kebutuhan akan perencanaan yang baik tidak hanya dirasakan oleh pemerintah yang memegang fungsi pengarah dan pengendali, tetapi juga oleh swasta, yang merasakan makin tajamnya kompetisi, dan menyadari bahwa keberhasilan bisnis ini juga tak terlepas dari situasi lingkungan yang lebih luas dengan dukungan dari berbagai sektor. Pada awal munculnya industri wisata di Indonesia dari segi Tata Ruang Nasional, pembangunan pariwisata hanya dikonsentrasikan pada beberapa lokasi seperti di NTB, Pulau Bali, Pulau Jawa, Sumatra Utara dan Sulawesi Selatan. Namun kini perkembangan pembangunan pariwisata berjalan cukup pesat setelah disadari, bahwa industri pariwisata merupakan penghasil devisa non migas terbesar di dunia. Idealnya, pariwisata dapat meningkatkan kualitas masyarakat dan mensejahterakan masyarakat, mendukung kelestarian lingkungan, mengembangkan perekonomian, dengan meminimalkan dampak negatif.

Sektor pariwisata memberikan kesempatan tumbuhnya berbagai usaha ekonomi yang dilakukan oleh masyarakat dan membuka lapangan kerja baik formal maupun informal bagi masyarakat. Jika dikelola dengan baik, sektor pariwisata dapat menjadi instrumen penting dalam konservasi sumberdaya alam dan mendorong tercapainya pembangunan berkelanjutan. Sektor pariwisata menyatukan dua atau lebih budaya yang berbeda. Wisatawan memperoleh pengalaman dari budaya lokal, sementara penduduk lokal memainkan jenis edukasi tentang lingkungan spesifik lokal dan mendapatkan penghasilan. Sinergi tersebut harus dapat dipelihara dengan kebijakan pemerintah yang kondusif bagi beroperasinya sektor swasta dan bantuan dari kelompok masyarakat. Partisipasi masyarakat memiliki peran penting dalam pengembangan pariwisata. Masyarakat harus berpikir terintegrasi dan jangka panjang untuk memperoleh manfaat dari sektor pariwisata antara lain peningkatan keterampilan, kesempatan kerja, peningkatan kesejahteraan, apresiasi nilai budaya dan manfaat konservasi lingkungan

Di Indonesia sektor wisata diantaranya agrowisata berkembang dengan pesat dan telah memberi kontribusi penting bagi pembangunan masyarakat pedesaan dengan sistem-sistem pertanian yang ada di pedesaan. Agrowisata merupakan bagian dari objek wisata yang memanfaatkan usaha pertanian sebagai objek wisata. Tujuannya adalah untuk memperluas pengetahuan, pengalaman rekreasi, dan hubungan usaha dibidang pertanian. Melaluipengembangan agrowisata yang menonjolkan budaya lokal dalam memanfaatkan lahan, pendapatan petani dapat meningkat bersamaan dengan upaya melestarikan sumberdaya lahan, serta memelihara budaya maupun teknologi lokal yang umumnya telah sesuai dengan kondisi lingkungan alaminya. Agrowisata yang berkembang ini, bukan saja menawarkan produk pertanian yang segar untuk dapat dijadikan konsumsi pengunjung juga dapat dinikmati konsumen dengan membeli langsung dari petani. Tetapi juga wisata ini menjadi sarana pendidikan serta hiburan yang menarik bagi para wisatawan. Agrowisata sebagai rangkaian berbagai aktivitas perjalanan wisata dengan memanfaatkan dan menikmati hasil-hasil pertanian dalam berbagai cara dan bentuk serta skala dalam memperoleh pemahaman, pengetahuan, pengalaman, dan menghibur wisatawan khususnya di bidang pertanian. Hal ini menunjukkan bahwa agrowisata bukan saja menawarkan produk hasil - hasil pertanian kepada pengunjung, tetapi juga menawarkan jasa untuk membuat pengunjung merasa puas dan terhibur bahkan dapat memiliki kemampuan untuk lebih memahami lagi tentang sektor pertanian jadi para pengunjung atau konsumen akan merasa betah dan bahkan dapat berulang - ulang mengunjungi lokasi wisata tersebut dan hal ini menunjukkan bentuk loyalitas pengunjung. Agrowisata yang berdaya saing dan secara ekonomi dapat dirasakan manfaatnya oleh masyarakat terkait dengan produk yang dihasilkan dan dikonsumsi oleh wisatawan. Produk - produk ekowisata dapat berupa paket-paket kegiatan dalam kawasan agrowisata yang dengan mengikuti paket 
tersebut wisatawan akan mendapatkan pengalaman baru dan kepuasan yang diharapkan.

Mengelola berbagai kepentingan secara proporsional dan tidak ada pihak yang selalu dirugikan atau selalu diuntungkan dalam kaitannya dengan pengalokasian ruang wisata. Kebijakan pengelolaan tata ruang tidak hanya mengatur yang boleh dan yang tidak boleh dibangun saja, namun terkandung banyak aspek kepastian arah pembangunan. Merubah potensi ekonomi menjadi peluang nyata, memproteksi ruang terbuka hijau bagi keseimbangan lingkungan, merupakan beberapa faktor yang perlu diperhatikan dalam upaya pengalokasian ruang. Pemerintah diharapkan dapat memberdayakan, mengayomi dan memberlakukan peraturan - peraturan, tidak sekedar untuk mengarahkan perkembangan, melainkan juga untuk perintisan atau untuk mendorong sektor-sektor pendukung dalam mewujudkan pengembangan pariwisata, yaitu mempunyai fungsi koordinasi, pemasaran, termasuk di dalamnya promosi, pengaturan harga untuk komponen - komponen tertentu, pengaturan sistem distribusi ataupun penyediaan informasi.

Setelah masa kemerdekaan Republik Indonesia tahun 1945 hingga kini kopi masih tetap bertahan dari segala perubahan zaman. Meski banyak juga yang telah beralih menjadi petani sayuran. Kebun kopi yang diserahkan kepada pemerintah itu terbengkalai. Bahkan kebun kopi yang dimiliki para petani itu di ketinggian sekitar 1.300sampai 1.600 meter diatas permukaan laut (MDPL) sudah masuk ke dalam wilayah Taman Nasional Gunung Rinjani. Namun hal ini juga dialami oleh masyarakat Sembalun. Desa yang identik dengan pemandangan petak sawah, perkebunan dan pegunungan tersebut ternyata memiliki sejumlah wisata di dalamnya. Salah satu diantaranya adalah agrowisata Sembalun yang masih belum banyak diketahui oleh banyak orang. disini juga ada agrowisata kebun kopi dan buahbuahan yang menjadi incaran para wisatawan tidak hanya itu bisa melihat aktivitas petani kopi secara langsung. Dengan ini, kalian bisa menanyakan seputar tentang kopi kepada para petani. Mulai dari cara pembibitan,penanaman sampai dengan jenis buah kopi yang sudah siap panen.

\section{Metode}

Penulisan Ini menggunakan metode deskriptif dan evaluatif. Metode deskriptif menggunakan data hasil survey sedangkan metode evaluatif digunakan untuk menilai persepsi masyarakat.

1. Metode deskriptif. Metode ini menggunakan data hasil survey untuk menggambarkan hal yang dibahas. Secara sistematis, faktual dan akurat mengenai fakta-fakta dan sifat-sifat populasi atau daerah tertentu.

2. Metode evaluatif. Metode evaluatif digunakan untuk menilai persepsi masyarakat terhadap pengelolaan agrowisata kebun kopi wilayah dusun Jorong Utara.

Penulisan ini dilaksanakan di Desa Sembalun Bumbung, Kecamatan Sembalun, Kabupaten Lombok Timur. Penelitian ini dilakukan kurang lebih 45 hari dari bulan Januari sampai Februari.

Pemilihan desa Sembalun Bumbung tepatnya di dusun Jorong Utara sebagai lokasi obyek Agrowisata yang dilakukan berdasarkan beberapa pertimbangan, yaitu adanya lokasi yang cocok atau strategis dan terdapatnya kebun kopi untuk mengembangkan agrowisata di daerah dusun jorong utara tersebut.

\section{Hasil dan Pembahasan}

Kopi Arabika adalah suatu usaha agrowisata kopi khususnya kopi arabika yang memiliki luas 4 lahan sekitar hektar di Kaki Gunung Rinjani tepatnya di Dusun Jorong Utara, Desa Sembalun Bumbung, Kecamatan Sembalun, Kabupaten Lombok Timur, NTB pada ketinggian 1.300 sampai 1.600 meter diatas permukaan laut (MDPL).Pada tahun 2016, lahan luas 4 hektar ini dimulai dengan budidaya buah-buahan sebagai tanaman penaung.Awalnya, usaha ini dibentuk bukan usaha Agrowisata melainkan usaha penginapan atau camping ground kemudian beliau (Bang Jacky) mempunyai inisiatif untuk mengembangkan Agrowisata khususnya buahbuahan seperti kopi, apel dan jeruk. Komoditas perkebunan seperti tanaman kopi pun mulai dibudidayakan di kebun Kopi Arabika dengan tujuan mengajak para petani sayuran di kawasan tersebut untuk mengubah pola pikirnya agar mau beralih ke komoditas perkebunan khususnya kopi dalam rangka mencegah terjadinya bencana longsor dengan membagikan bibit kopi secara gratis untuk dibudidayakan di lahan para petani tersebut, mengembalikan sumber mata air, dan dapat 
meningkatkan kesejahteraan petani di kawasan Sembalun Bumbung. Budidaya tanaman kopi yang dipadukan dengan tanaman buah-buahan di kebun Kopi Arabika ternyata memberikan dampak baik bagi para petani kedepannya. Pemilihan benih unggul dan perlakuan benih yang tepat, pengolahan lahan, teknik penanaman, penggunaan tanaman naungan, pemeliharaan (pemberantasan hama dan penyakit, serta pemangkasan), dan teknik pemanenan, sangat menentukan jumlah mutu produksi kopi. Maka dari itu berikut merupakan proses pembibitan hingga menjadi suatu luaran atau produk yang sudah jadi.

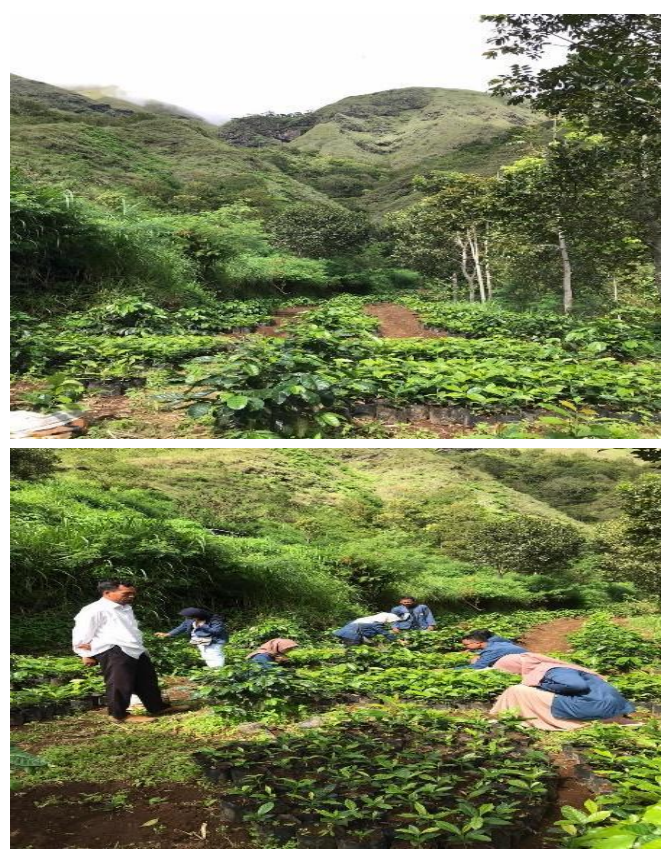

Gambar 1. tanaman kopi tradisional masyarakat di Desa Sembalun Bumbung, Kecamatan Sembalun, Kabupaten Lombok Timur

Gambar 1 diatas memperlihatkan,bibit kopi lokal yang diperoleh dari kebun masyarakat setempat. Sebagian kecil dari mereka melakukan pembenihan (persemaian dan penggunaan polybag). pemilihan bahan tanam unggul merupakan langkah penting dalam praktek budidaya kopi yang baik. Dalam pemilihan bahan tanam unggul perlu dipertimbangkan kesesuaian dengan lingkungan tempat penanaman agar dapat diperoleh mutu citarasa dan produktivitas yang maksimal. Bibit kopi yang digunakan oleh petani pada penelitian ini berupa bibit sapuan yang dicabut dan ditanam langsung ke areal penanaman pada musim penghujan. Areal penanaman dibersihkan dan dilakukan pengolahan tanah, dan kemudian ditanami.

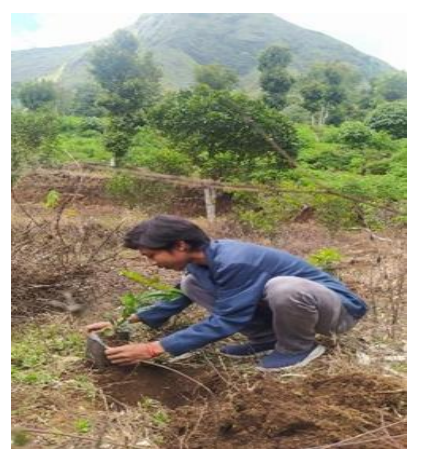

Gambar 2. penanaman bibit kopi arabika di Desa Sembalun Bumbung, Kecamatan Sembalun, Kabupaten Lombok Timur.

Dalam penanaman bibit ini diperlukan lahan dan bibit yang sudah siap, Langkah selanjutnya memindahkan bibit dari polybag ke lubang tanaman di area kebun petani di dusun Jorong Timur. Jarak tanam budidaya kopi yang dianjurkan adalah 2,5x2,5 meter untuk arabika. Jarak tanam ini divariasikan dengan ketinggian lahan sebesar 1.600 mdpl. Semakin tinggi lahan semakin jarang dan semakin rendah semakin rapat jarak tanamnya. Buat lubang tanaman dengan ukuran $30 \times 30 \mathrm{~cm}$ pembuatan lubang ini dibuat sebelum penanaman. Kini Bibit kopi siap ditanam di lubang yang sudah disiapkan sebelumnya papas daun yang terdapat pada bibit hingga tersisa $1 / 3$ bagian untuk mengurangi penguapan. Keluarkan bibit kopi dari polybag kemudian digali sedikit lubang tanam yang telah dipersiapkan masukkan bibit kemudian tutup lubang tanam agar tanaman berdiri kokoh.

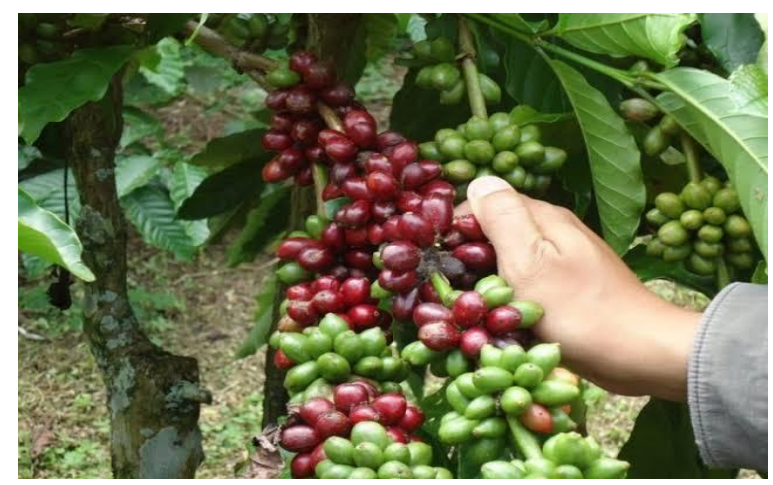

Sumber: internet (www.bakti negeriku.com) 


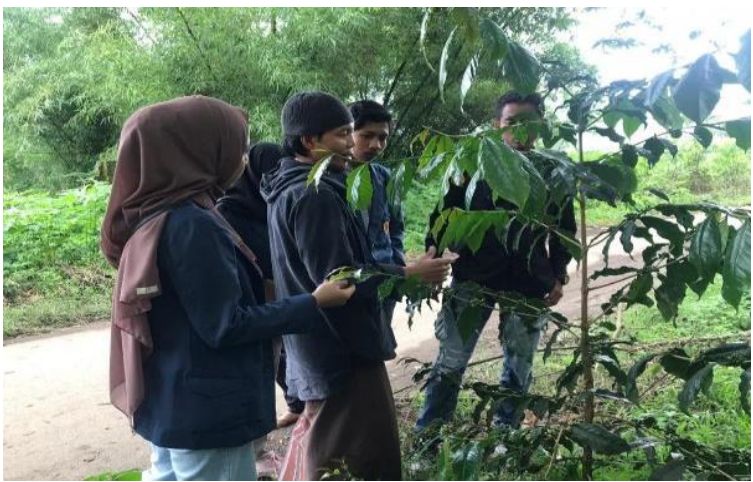

Gambar 3. Panen dan pasca panen bibit kopi arabika di Desa Sembalun Bumbung, Kecamatan Sembalun, Kabupaten Lombok Timur.

Tanaman yang dibudidayakan secara intensif sudah bisa berbuah pada umur 3-4 tahun untuk jenis kopi arabika. Hasil panen pertama biasanya tidak terlalu banyak produktivitas tanaman kopi akan mencapai puncaknya pada umur 7-9 tahun. Panen Budidaya kopi dilakukan secara bertahap, panen raya biasa terjadi dalam 4-5 bulan pada bulan April dan mei dan panen kopi ini terjadi 1 tahun 2 kali dengan interval waktu pemetikan setiap 10-14 hari. Panen dan pengolahan pasca panen akan menentukan mutu produk akhir.

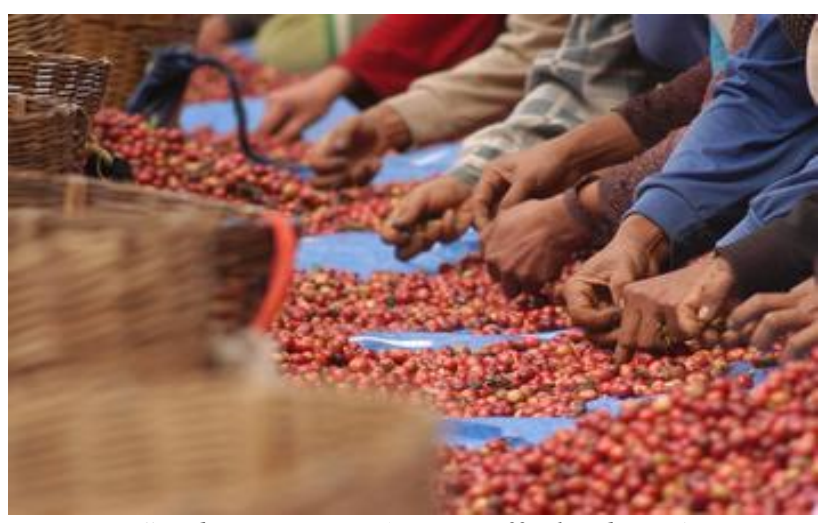

Sumber: internet (www.coffeelend.com)

Gambar 4. Sortasi (memisahkan) bibit kopi arabika di Desa Sembalun Bumbung, Kecamatan Sembalun, Kabupaten Lombok Timur.

Sortasi buah kopi yang dilakukan di kedai kopi kay bertujuan untuk memisahkan buah yang superior (masak, bernas dan seragam) dari buah inferior (cacat, hitam, pecah, berlubang, dan terserang hama / penyakit). Sortasi buah kopi ini juga bertujuan untuk menghilangkan kotoran seperti daun, ranting, tanah, dan kerikil karena pengotor tersebut dapat merusak mesin pengupas kulit.

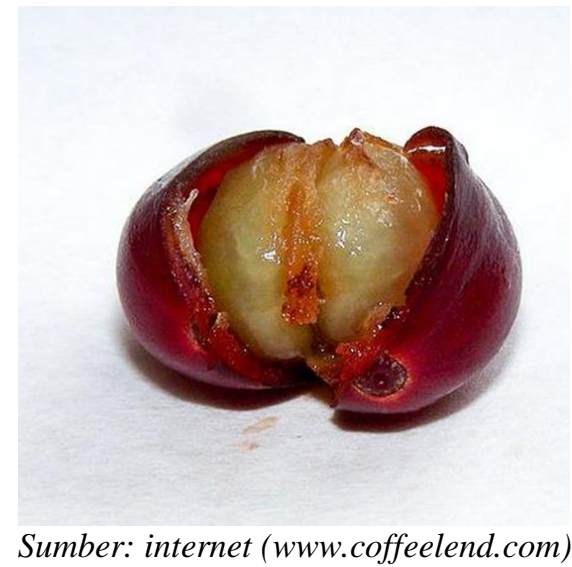

Gambar 5. pengupasan dan proses fermentasi kopi arabika di Desa Sembalun Bumbung, Kecamatan Sembalun, Kabupaten Lombok Timur.

Pengupasan Kulit Buah Dilakukan pada awal metode basah pengolahan biji kopi. Pengupasan kulit buah dilakukan dengan alat pengupas tipe silinder. Pengupasan Buah kopi dilakukan dengan menyemprotkan air ke dalam silinder bersama dengan buah kopi yang akan dikupas. Aliran air ini berfungsi untuk membantu mekanisme pengaliran buah kopi kedalam silinder dan sekaligus membersihkan lapisan lendir. Selain itu, air juga berfungsi untuk mengurangi tekanan geseran silinder terhadap buah kopi sehingga kulit tanduk nya tidak pecah.

Proses fermentasi bertujuan untuk menghilangkan lapisan lendir yang tersisa di permukaan kulit tanduk biji kopi setelah pengupasan. Selain Itu Fermentasi juga bertujuan untuk mengurangi rasa pahit dan mendorong terbentuknya kesan "mild" pada cita rasa seduhannya. Prinsip Fermentasi Adalah Peruraian Senyawa-senyawa yang terkandung di dalam lapisan lendir oleh mikroba alami dan dibantu dengan oksigen dari udara. Proses fermentasi dapat dilakukan secara basah (direndam di dalam genangan air) dan secara kering (tanpa rendaman air). Proses fermentasi ini biasanya dilakukan pada kopi arabika. 


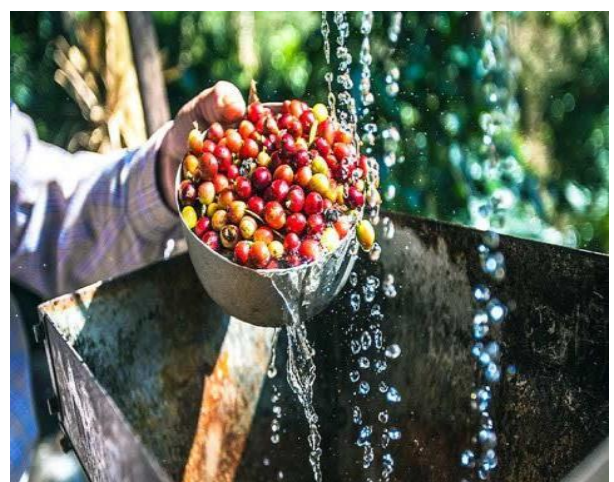

Sumber: internet (www.coffeelend.com)

Gambar 6. pencucian kopi arabika di Desa Sembalun Bumbung, Kecamatan Sembalun, Kabupaten Lombok Timur.

Pencucian bertujuan untuk menghilangkan sisa lendir hasil fermentasi yang masih menempel di kulit tanduk. Prinsip Pencucian Ini Adalah Memasukkan Biji kopi arabika kedalam corong silinder secara kontinyu dan disertai dengan semprotan air kedalam silinder. Sirip Pencuci yang diputar dengan motor bakar mengangkat massa biji kopi ke permukaan silinder, sambil bergerak, sisasisa lendir pada permukaan kulit tanduk akan terlepas dan tercuci oleh aliran air. Kotoran-kotoran akan menerobos lewat lubang-lubang yang tersedia pada dinding silinder, sedang massa biji kopi yang sudah bersih terdorong oleh sirip pencuci ke arah ujung pengeluaran silinder.

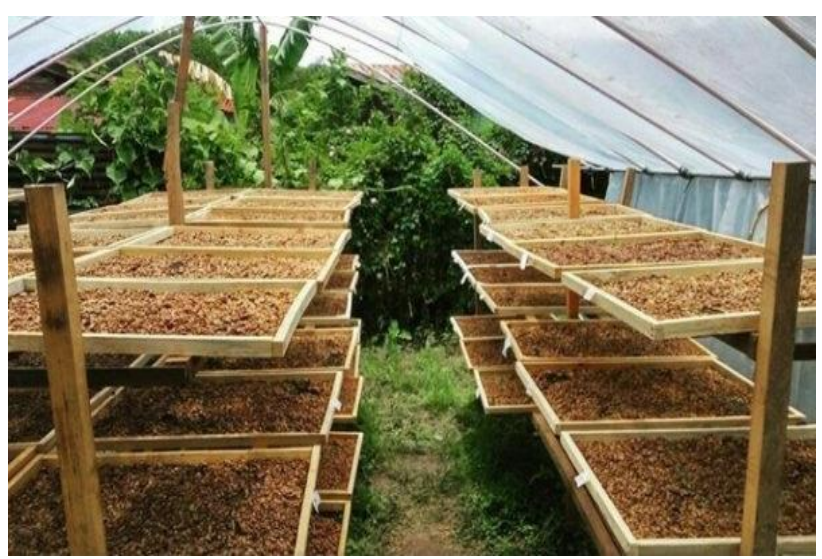

Sumber: internet (www.coffeelend.com)

Gambar 7. Pengeringan kopi arabika di Desa Sembalun Bumbung, Kecamatan Sembalun, Kabupaten Lombok Timur.

Dilakukannya proses pengeringan di kedai kopi kayu bertujuan untuk mengurangi kandungan air dalam biji HS yang semula $60-65 \%$ sampai menjadi 12 - 13\%. Proses penjemuran dapat dilakukan dengan berbagai cara, diantaranya adalah dengan cara penjemuran di bawah sinar matahari, mekanis, dan kombinasi keduanya.

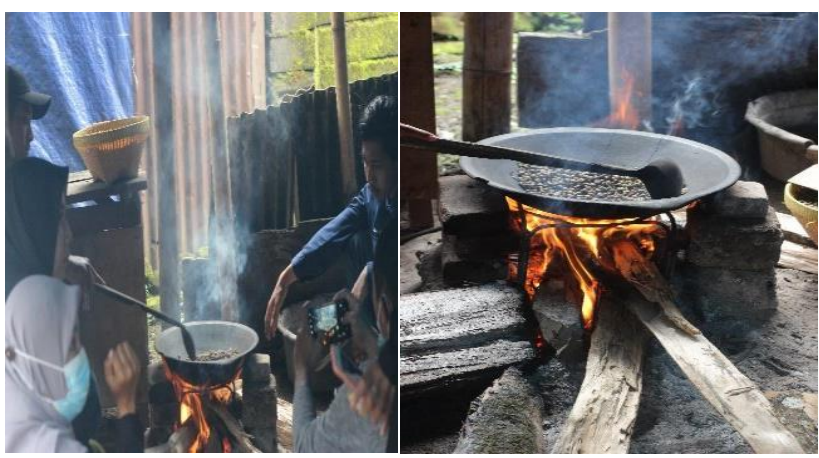

Gambar 8. Penyangraian kopi arabika di Desa Sembalun Bumbung, Kecamatan Sembalun, Kabupaten Lombok Timur.

Penyangraian Merupakan Suatu proses yang penting pada pembuatan kopi bubuk. Penyangraian Bertujuan Untuk Menurunkan Kadar air biji sampai di bawah $4 \%$ dan bertujuan untuk membentuk aroma dan citarasa khas kopi. Proses penyangraian dapat menyebabkan perubahan fisik dan kimiawi yaitu penguapan air daripada biji, penguapan senyawa volatil (aldehid, furfural, keton, alkohol, dan ester), serta proses pirolisis atau pencoklatan buah.

Berdasarkan suhu penyangraian yang digunakan kopi sangrai bedakan atas 3 golongan yaitu light roast suhu yang digunakan $193^{\circ} \mathrm{C}$ sampai $199^{\circ} \mathrm{C}$, medium roast suhu yang digunakan $204^{\circ} \mathrm{C}$ dan dark roast suhu yang digunakan $213^{\circ} \mathrm{C}$ sampai $221^{\circ} \mathrm{C}$. Light roast menghilangkan $3-5 \%$ kadar air, medium roast menghilangkan $\quad 5-8 \%$ dan dark roast menghilangkan $8-14 \%$ kadar air (Varnam and Sutherland, 1994). Namun Dalam Penyangraian kopi ini kami melakukannya dengan cara tradisional.
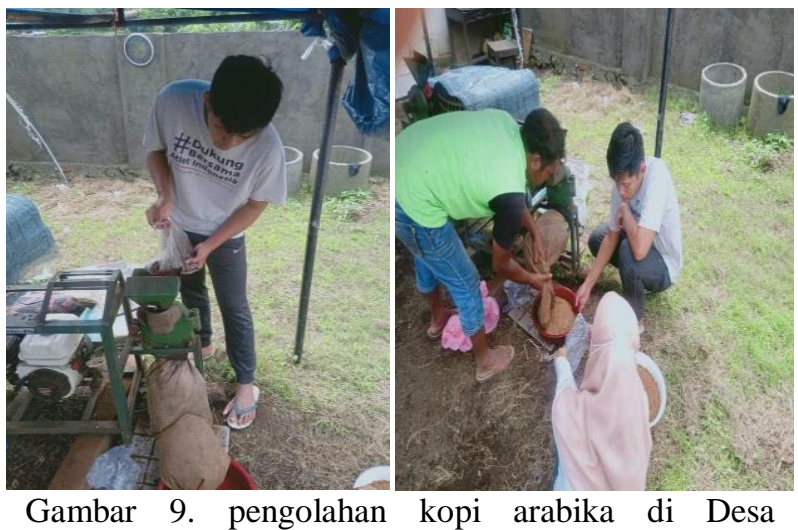
Sembalun Bumbung, Kecamatan Sembalun, Kabupaten Lombok Timur.

Proses penghalusan biji kopi dilakukan di rumah pak kadus hairul di bebante dengan alat penghalus (mesin huller kopi) sampai diperoleh kopi bubuk dengan ukuran partikel tertentu. Ukuran Partikel kopi bubuk ini sudah sesuai dengan ukuran yang biasa dijual belikan di pasaran. Butiran bubuk kopi mempunyai luas penampang yang besar sehingga senyawa pembentuk cita rasa mudah larut kedalam air panas.

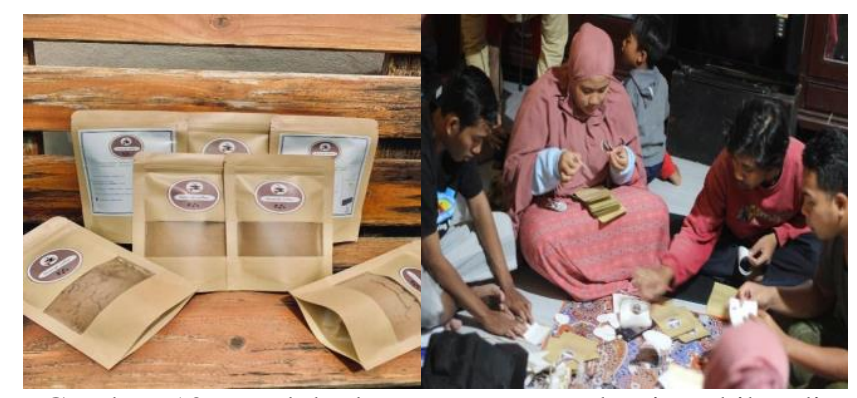

Gambar 10. produk dan pengemasan kopi arabika di Desa Sembalun Bumbung, Kecamatan Sembalun, Kabupaten Lombok Timur

\section{Pengemasan Bertujuan Untuk}

Mempertahankan aroma dan citarasa kopi bubuk yang akan didistribusikan. Beberapa Faktor yang dapat berpengaruh terhadap keawetan kopi bubuk selama dikemas adalah kondisi penyimpanan, tingkat sangrai, kadar air kopi bubuk, kehalusan bubuk, dan kandungan oksigen di dalam kemasan. Kemasan yang mengandung terlalu banyak oksigen dapat menyebabkan aroma dan citarasa kopi berkurang karena proses oksidasi. Sedangkan Kandungan air yang terlalu banyak di dalam kemasan akan dapat menghidrolisis senyawa kimia yang ada di dalam kopi bubuk dan menyebabkan bau apek.

\section{Potensi Agrowisata Kopi Arabika}

Pada awalnya, kegiatan wisata ini dilakukan karena adanya keinginan pecinta kopi Arabika yang penasaran dengan cara penanaman Kopi Arabika yang diproduksi oleh Bang Jecky. Selain itu, Kopi Arabika juga dikunjungi oleh wisatawan nusantara dan mancanegara.

\section{Objek Wisata Kopi Arabika}

Kegiatan wisata Kopi Arabika yang dilakukan mengelilingi kebun kopi seluas 4 hektar sambil diberikan pengarahan dan edukasi mengenai budidaya tanaman kopi mulai dari penyiapan lahan dan pohon penaung, pembibitan tanaman kopi, pemeliharaan tanaman kopi dan panen. Selain itu, wisatawan diajak untuk menanam bibit kopi di lahan yang telah disediakan dalam rangka membantu melestarikan lingkungan kawasan di bawah Gunung Rinjani dan menjadi kenangkenangan bagi wisatawan.

2. Sarana dan Penunjang Objek Wisata Kopi Arabika

Fasilitas rekreasi yang ada dilingkungan tersebut adalah

- Camping Ground untuk tempat para tamu menginap menggunakan tenda.

- Tanaman Buah-buahan (Agro) seperti: kopi, apel, dan jeruk, yang bisa dinikmati oleh para pengunjung atau wisatawan di tempat tersebut.

- Spot Foto yang dapat digunakan oleh para pengunjung untuk berfoto-foto ceria.

- Cafe Coffee yang dapat dinikmati sambil bersantai.

Selain itu, sarana pelengkap yang dimiliki oleh Kopi Sembalun yaitu:

- Letak kebun kopi yang berada di bawah kaki Gunung Rinjani, tepatnya di kawasan Sembalun Bumbung, menyebabkan wisatawan harus menaiki kebun kopi agar mencapai camping ground, ini menjadi salah satu daya tarik bagi wisatawan.

- Adanya listrik dan air bersih yang bersumber dari mata air dari kaki Gunung Rinjani

- Kebun kopi Sembalun menyediakan sebuah lahan untuk camping ground sebagai tempat menginap bagi para wisatawan tersebut.

\section{Kesimpulan}

Kebun kopi Sembalun mempunyai potensi agrowisata yang cukup baik, namun terdapat pula kelemahan seperti keterbatasan dana, kurangnya sarana dan prasarana penunjang, serta kurangnya atraksi wisata yang ditawarkan. Kebun kopi Sembalun yang paling menonjol adalah objek wisata yang ditawarkan bersifat rekreasi dan edukatif. Diharapkan Pada Instansi agar melakukan Pengembangan Agrowisata khususnya Kopi bagi kelompok pengembang di Sembalun bumbung untuk meningkatkan kualitas produk dan meningkatkan potensi Agrowisata di Desa 
Sembalun Bumbung. Diharapkan kepada anak muda Sembalun Bumbung dan sekitarnya untuk mengikuti dan meningkatkan perhatian terhadap potensi ekonomi lokal agar terjadi regenerasi dalam usaha Agrowisata di Sembalun Bumbung.

\section{Ucapan Terima Kasih}

Ucapan Terima kasih kepada bapak Rektor melalui LPPM Unram dan Kepala Desa Sembalun Bumbung yang telah membantu pelaksanaan kegiatan mahasiswa KKN Unram.

\section{Daftar Pustaka}

Jojok Dwiridotjahjono, dkk, 2017. Pengembangan Agroekowisata Berbasis Perkebunan Kopi Rakyat di Kecamatan Tutur, Kabupaten Pasuruan.

Badan Pusat Statistik. 2015. Produksi Kopi Di Indonesia. Badan Pusat Statistik, Jakarta.

Rahardjo, P. 2012. Panduan Budidaya dan Pengolahan Kopi Arabika dan Robusta. Penebar Swadaya, Jakarta.

https://www.baktikunegeriku.com/ diakses pada tanggal 08 Februari 2021, pukul 06:00 WITA

www.coffeelend.com/diakses pada tanggal 08 Februari 2021, pukul10:00 WITA 